\title{
Review
}

\section{Systemic corruption: Constitutional ideas for an anti-oligarchic republic}

\author{
Camila Vergara \\ Princeton University Press, Princeton and Oxford, 2020, 312 pp., \\ ISBN: 978-0691207537
}

Contemporary Political Theory (2022) 21, S31-S33. https://doi.org/10.1057/s41296021-00472-2; Published online 9 February 2021

Given the size and complexity of contemporary public administrations, the idea that political corruption consists of more than the actions of individual public officials seems quite reasonable. Journalists, groups of civil society, and district attorneys do not stop their investigations at the misdeeds of a particular official; rather, the main objects of those inquiries are often networks of corruption. But even though we are well aware of the social relationships in which corruption is necessarily embedded, this does not prevent us from falling into a sort of legal positivism - that is, activities are considered 'corrupt' only when they are outside the law. In Systemic Corruption, Camila Vergara wrestles precisely with this issue: there is a subset of conducts that go against the public good and yet are legal and systematically carried out by public officials. Her book aims to develop the conceptual tools and institutional mechanisms to account for and fight against such 'systemic' corruption - a slow-moving process that happens not despite the formal rules of liberal democracies, but because of them. Systemic Corruption puts forward a bold materialist, realist, anti-oligarchic, and radical-democratic social theory, ending up with a detailed proposal for a plebeian branch to be incorporated into the US Government.

A main inspiration for Vergara's systemic focus in the analysis of corruption comes from a certain critical approach to the study and practice of liberal democracy. Against proceduralist, elitist, and legal-positivist approaches that arguably inspire mainstream lines of research and political reform, she deploys a 'material constitutionalism' concerned with the 'factual organization and exercise of power that is allowed and enabled by foundational institutions, rules, and procedures - or the lack thereof' (p. 102). This perspective is premised on the understanding that 'the organization of political power cannot be analyzed without taking into account the socioeconomic power structure, and how the state enables some kinds of actions while disabling others ... through the selective enforcement of rules and penalties that appear as neutral' (p. 102).

(C) 2021 The Author(s), under exclusive licence to Springer Nature Limited part of Springer Nature. 14708914 Contemporary Political Theory Vol. 21, S1, S31-S33 www.palgrave.com/journals 
One of the most important insights for today's political and social theory is the way in which Vergara is able to separate her material constitutionalism from any substantive political project - and this does not mean that she hides her normative preferences. We may say that Vergara's material constitutionalism consists of two stages. The first stage is chiefly epistemological: it embeds constitutional thought and reform into existing distributions of socioeconomic power. The second stage is strongly normative, anti-oligarchic, and, if you will, 'partisan', ultimately leading to her proposal for a plebeian branch of government: a multi-level network of local assemblies and councils with remunerated activities and several 'tribunate' offices with power of impeachment, prosecution, and able to command the state's forces of order in case of necessity. Anyone with one-year residence who does not occupy a 'position of political, judicial, cultural or religious authority', or act as 'lobbyist for wealthy individuals and corporations', can be a member of a local assembly and thus voluntarily elected by lot for a council or a tribunate office (p. 252).

Vegara's explicitly plebeian commitment, however, does not make her position a less formidable enemy to her critics. Even if one could argue, in purely normative terms, against a constitutional reform with a strong plebeian or anti-elitist bent (or about the contingent features of such a proposal), one must first deal with the empirical concerns raised by Vergara's sociological and political-economic awareness. And anyone committed to the normative core of liberal democracies (or the more basic idea that public officials ought to foster the public good) who is also convinced by her materialist epistemic approach, should agree on the oligarchic danger present in our polities and, therefore, accept some way of institutionalizing an anti-oligarchic power.

From a proceduralist or legal-positivist point of view, rejecting Vergara's socioeconomic standpoint seems very difficult, at least for two reasons. The first is that she consistently applies her materialist epistemology in the history of western political thought, not merely to plebeian-leaning thinkers, but also to clear-cut elitists. She demonstrates that caring for real struggles and pre-existing distributions of power has been a pervasive feature of the constitutional tradition independently from the political projects involved in those institutional arrangements. For instance, she shows that Machiavelli's constitutional plebeianism was as informed by socioeconomic concerns as the most elitist wing within the US Constitutional Convention. Second, by revealing the actual materialist and realist concerns of the western constitutional canon, Vergara also reveals the class-based and oligarchic design behind many of today's apparently neutral foundational institutions - and with that, their ineluctable disposition toward a systemic corruption detrimental to the public good.

While in most sections Vergara accounts for the conjunctural political and socioeconomic struggles involved in constitutional thought, her reconstruction of historical contexts feels patchy at times. The very compelling political-economic and sociological takes on republican Rome, Machiavelli's Florence, the US

S32 (C) 2021 The Author(s), under exclusive licence to Springer Nature Limited part of Springer Nature. 14708914 Contemporary Political Theory Vol. 21, S1, S31-S33 
founding era, and Rosa Luxemburg's Germany are absent in the sections about Condorcet, Montesquieu, and Arendt, where an internalist analysis of their texts prevails over the well-informed contextualism of other chapters. While this gap does not undermine Vergara's main argument, some hermeneutic questions arise. For instance, why should we take into account debt and propertylessness in the USA in the eighteenth century to figure out Madison's constitutional views or interwar party politics in order to grasp Luxemburg's materialism, but ignore similar historic circumstances in the USA in the twentieth century when approaching Arendt's thought on the matter?

Systemic Corruption is neither about embezzlement, bribery, and nepotism, nor about non-virtuous officials. Instead, the object of study is how liberal democracies, as they have been designed, cannot avoid oligarchization and thus systematically prevent the fulfillment of many of the purposes whose champions they boastfully proclaim to be. In the face of a political theory devoid of the conceptual and normative tools to understand the necessary (and historical) relationship between social struggle and constitutionalism, Vergara illuminates a path to re-incorporating political economy and a well-tempered realism into our legal and political thought. The fact that in Systemic Corruption this path leads to careful anti-oligarchic constitutional reform only shows the promising future for this forgotten perspective whenever it is restored with a deep concern for freedom and democracy.

Publisher's Note Springer Nature remains neutral with regard to jurisdictional claims in published maps and institutional affiliations.

David Guerrero

University of Barcelona, 08007 Barcelona, Spain david.guerrero@ub.edu 